\title{
Exploring the development of a hybrid and synthetic meaning of citizenship at a British university law school
}

\author{
Piers von Berg \\ University of Plymouth and Institute of Education, University College London \\ Corresponding Author: Piers.vonberg@plymouth.ac.uk
}

(Submitted: 17 June 2019; Accepted: 5 December 2019)

\begin{abstract}
This study uncovers a previously underappreciated role of the social experience of university in shaping undergraduates' civic identities. A multidisciplinary theoretical approach to citizenship is used to understand an individual's attempts to negotiate meaning along with a qualitative methodology that allowed students a voice in the data collection and analysis. The findings show that some of the most formative experiences in a student's civic identity is their interaction with peers and friends in a diverse student community. There is also a strong influence of a culture of performativity and credentialism on students' attitudes to learning about citizenship. Both combine in a 'synthetic civic identity' shaped by a mixed environment of more open-minded civic norms and an instrumental and individualist outlook towards studies. There were varying degrees of critical awareness or reflexivity around these processes. This hybrid form of civic identity stimulates and challenges current narratives of tension in higher education.
\end{abstract}

Keywords: citizenship, civic identity, higher education, students

\section{Introduction}

In the last ten years, there has been a resurgence of interest in the civic role of universities in the U.K. This is a return of an old idea: universities have long been associated with ideas of social transformation, going back to Cardinal Newman in 1852 and beyond (Newman, 2008). There are many contemporary views that see universities as nurturing democracy (e.g. Barrie and Prosser, 2004; Benson et al., 2007; Habermas cited in Walker and McClean, 2013), one of the many competing demands on their role (Gutmann, 1987; Watson, 2006). In the U.K., there has been renewed interest in the idea of a 'civic university' and in engagement with communities (Goddard, 2010; McCowan, 2012), and distinct from this, that universities can cultivate the attributes of citizenship as part of the student experience. For example, a number of U.K. universities now declare that their students will 
obtain attributes of citizenship as part of their experience at university. ${ }^{1}$ Curiously, there has not been any widespread adoption of any formal citizenship education courses at universities (McCowan, 2012). This raises the question of how students obtain attributes of citizenship from their experience at university, if at all. This is an important question because in the U.K. a far greater number of students now attend university than in previous times and spend longer in higher education (Furlong and Cartmel, 2007; 2009). In commenting on similar trends in the United States, some argue that universities have become 'the central institution for civic incorporation of younger generations' (Flanagan and Levine, 2010: 159).

There is little research on how students construct meanings of citizenship and thereby their civic identities from their experiences at university in the current context of higher education in the U.K. Whilst South African campuses contain many divisions along racial, ethnic, and socioeconomic lines, U.K. universities have become increasingly diverse with the increase in student intake. How this influences the students' experience and understanding of citizenship and civic education is an open question in the U.K. and emerges as an important theme in this study. One can focus specifically on undergraduates, who are often at formative junctures in their lives as young adults and newly fledged citizens in the legal sense. If one understands education as a process of communication reliant on active meaning-making by participants (Biesta and Lawy, 2006), this merits a study of undergraduates' experience of citizenship and how they construct meaning around it as a means of understanding their education about citizenship at university.

Such a study into the meanings of citizenship must first acknowledge that citizenship is a problematic term in the U.K. because historically it lacks emotional and historical resonance (Ahier, et al., 2003; Osler and Starkey, 2005). Citizenship is also difficult to pin down theoretically. It is a term whose multiple meanings in various disciplinary, political, and cultural contexts leads some to argue that there can or should be no agreed meaning (Plant cited in Storrie, 2004; Shachar et al., 2017) or that it risks becoming meaningless (Davies et al., 2002; Clarke et al., 2014). The environment of this study is the changing landscape of U.K. higher education characterised by greater numbers of students, privately funded education, and marketing of universities and employers to students (Scott, 2010). These processes have affected some disciplines more than others, especially law (Thornton, 2009), which is my own professional context. Law is also a discipline with a unique civic character: students study subjects with civic content, volunteer in legal clinics, and might aspire to be lawyers, who can be 'highly influential citizens' (Nussbaum, 2003: 271). Therefore, a law school seemed an apposite location to investigate students' experiences of citizenship in a milieu of cross cutting currents of institutional reform and opportunities for

\footnotetext{
${ }^{1}$ As an illustrative example, an internet search by the author on 04.10 .17 found these 23 websites of U.K. universities to contain references to citizenship as their declared strategy or marketing material: Aberdeen, Abertay, Anglia Ruskin, Bath Spa, Birmingham, Bradford, Bristol, Edinburgh Napier, Exeter, Glasgow Caledonian, Hertfordshire, Kent, Manchester, Oxford Brookes, Nottingham Trent, Plymouth, Queen Mary, Sheffield, Staffordshire, U.C.L., U.E.A., Ulster and Westminster. For example: https://www.abertay.ac.uk/media/2964/2016_a_to_z_guide.pdf.
} 
civic learning. The literature review surveys the relevant literature on citizenship, young people, and university before presenting and analysing the data.

\section{Citizenship, young people and university}

Citizenship is a problematic and a disputed term. Whilst many agree that to be a citizen is to be a member of a political community (Clarke, et al., 2014; Joppke, 2007; McCowan, 2009; Osler and Starkey, 2005) and citizenship can be understood as that status of being such a citizen, there is little consensus beyond this (see Shachar, et al., 2017). This is because membership of a political community involves questions on which there will always be disagreement, such as the nature of the State, our obligations to one another, and the scope of rights (Kymlicka, 2002; Plant cited in Storrie, 2004). Such arguments are also the subject matter of contemporary politics. At the time of this study, the students had recently had the opportunity to vote in the referendum on the U.K.'s membership of the European Union, the result of which may end their citizenship of the European Union. Therefore, citizenship is more than 'an academic concept' (Clarke, et al., 2014: 1). It is a word upon which many hang claims and use to make claims (Isin, 2017). It is also more than status. It has meaning, which can be imbued with feeling that can in turn shape behaviour. My focus is on an individual's conceptualisation of the meaning of citizenship.

Therefore, a preliminary word of caution is needed when using the term 'citizenship'. Citizenship is often a tool either to reframe arguments about theories of justice (Kymlicka, 2002) or to mount claims to challenge inequitable or unjust social hierarchies and structures (Lister, 2007). It is both a concept for analysing power and one used to regulate power and identity (e.g. through inclusion and exclusion) and exert power (e.g. through rights). This is complicated when one turns as an adult researcher to young people, who sit in an uneven power relationship with society (Smith, et al., 2005). Therefore, one should consider the reflexive dimensions of the term when researching citizenship and young people. For example, how aware are students of how society wishes them to be a citizen and how aware are we as researchers of our preconceptions of young people as citizens? A persistent theme in the literature is that young people are incomplete citizens and, therefore, in need of help to become better citizens for the sake of the society in question (Shaw, et al., 2014; Smith, et al., 2005; Wood, 2014).

The approach employed here recognises a development from a top-down political socialisation model, where young people are molded into citizens by socialising agents, such as parents and schools, towards a more socially constructed understanding of citizenship (Amnå, 2012; Haste, 2010). This multidisciplinary approach draws on developmental psychology, education, and sociology that posits a 'growing individual as an active agent, in dialogic relation to the social and cultural context' (Haste, 2010: 182). It is a useful model because it recognises the interaction between individual choice and context. It combines well with a sociological approach to citizenship that theorises citizenship as a changing social construct affected by historical context at a macro level and at an individual level one that is intelligible as 'norms, practices, meanings, and identities' (Isin and Turner, 2002: 4). 
Therefore, citizenship is a theoretical construct and a social and political reality, which enables us to talk about our relationships with one another and the State. We can ask how reflexive we are of those relationships, especially when talking about, and to, young people, who are developing their capacities and vulnerable to manipulation for ideological ends.

This multidisciplinary and reflexive understanding of citizenship is helpful in examining young people's experience of it. Citizenship is a lived experience and practice, infused with meaning that is linked to a set of values and beliefs that inform action (Osler and Starkey, 2005). The meaning ascribed to citizenship can be understood using identity. Identity is a continuing lifelong process of coming to understand and represent oneself reflexively using beliefs, values, goals, roles and experiences that can be integrated across time, space and social realms, and yet also exist separately as compound parts (Giddens, 1991; Pollard, 2003; Nagaoka et al., 2015; Sennett, 2001). Young people's identities shape their citizenship e.g. as politics of lifestyle in affluent societies (Osler and Starkey, 2005). It is a dynamic state where reflection on one's actions and experience leads to further additions to one's own personal narrative. I distinguish this from normative definitions of civic identity as 'individual and collective senses of social agency, responsibility to society, and political-moral awareness' (Youniss, et al., 2001: 620).

A person's civic identity is grown in a specific context. Theorists of citizenship and identity argue that citizenship should be understood in reference to ethnic, cultural, national, and gendered contexts (Isin and Wood, 1999). This notion of citizenship as a lived experience leads to an understanding of citizenship that is sensitive to individual agency, position and the interaction between them. This allows a differentiation in one's understanding of citizenship as individuals experience it in different, forms, spaces, and moments (Isin and Wood, 1999). This can be a manipulated state and not one an individual is entirely critically aware of.

This approach to citizenship that foregrounds identity is particularly helpful when researching young people and citizenship. A central task of young people aged 15-22, including university undergraduate students, is the formation of identity (Erikson, 1968). Young people's experience at university is characterised by greater attention to and choice of what to believe, who to associate with, what invest time in, choice of partner, desired career and so forth. Some argue that identity is constructed by the individual with less collective support and cultural reference points, a process sociologists term 'individualisation' (Côté and Schwartz, 2002). With citizenship, the picture is more complex. On the one hand, there is greater preference for one-off online petitions and single issue campaigns rather than regular voting and political party allegiance (Furlong and Cartmel, 2007), and, on the other, structural inequalities and barriers such as gender, class, and race are still a pervasive influence on young people's capacity for agency (Furlong and Cartmel, 2007). What is disputed is whether young people are autonomous or agentic architects of their own identity and to what degree they are constrained by or even critically aware of the influence of social structures (Amnå, 2012; Furlong and Cartmel, 2007; Jones, 2009). 
How undergraduate students experience and conceptualise civic identity is underexplored using a multidisciplinary approach to identity. Many studies of youth citizenship focus on more orthodox forms of civic engagement and political participation such as volunteering and voting (Shaw, et al., 2014). They miss more mundane interactions in which young people construct meanings of citizenship in their everyday lives (Biesta and Lawy, 2006; Wood, 2014). Those who look at the meaning given to citizenship by young British people do not focus exclusively on young people at university age (e.g. Youth Citizenship Commission, 2009) or where they do, do not examine its formation at university (Lister, et al, 2003; Wood, 2014). Rare instances of studies of the effects of university on citizenship predate significant changes to higher education (Ahier, et al., 2003; Bynner, et al., 2003), focus on similar themes but in other disciplinary contexts (McClean, et al, 2017), or occur in foreign contexts (e.g. the United States in Colby, et al., 2007 and Australia in Ryan 2011).

The need for fresh studies in the U.K. is due to the expansion in student intake leading to greater diversity (Scott, 2010). Diversity and plurality are also evident in the South African higher education context with racial, ethnic, and socioeconomic divides. In the U.K., the tripling of tuition fees in 2012 means this larger more diverse student body is a major source of income for universities and so targeted by and used in university marketing to students. This has led some to describe quality in higher education as the consumer power of students in a competitive market of universities (critically by Ashwin and McVitty, 2014, and McClean, et al., 2017, and positively in Barber, et al., 2013). This is not sufficiently addressed in the literature on citizenship in U.K. higher education. Smyth (2016: ix) argues that studies are needed that 'give existential accounts of what life is like for students in the contemporary university [emphasis in original]' so that we understand 'the nature of the stresses and strains, and the consequences these market-driven distortions have for the learning experiences of students, their lives and futures' (ibid.).

Before we consider this more, we must first acknowledge that students arrive at university with norms, values, and interests drawn from the communities and families they grew up in. As children, they learned about citizenship by internalising norms and ideology of their family and community through a huge range of experiences of inclusion, exclusion, rights, and accountability (Flanagan and Levine, 2010). At university, students are constrained and shaped by expectations and tasks of their discipline and the values of family and friends (Colby, et al., 2003; Macfarlane, 2015). Substantial quantitative and longitudinal studies show that volunteering in extracurricular activities with a prosocial and democratic element (McFarland and Thomas, 2006) and the gradual process of maturation and emergence of individual autonomy of a young adult, especially through service learning (Flanagan and Levine, 2010) predicate future civic activism. Others argue that critical enquiry at university enables us to 'conceptualise the notion of citizenship and bring about its flourishing in any given society in an adequate way' (Annette, 2010: 451). Similarly, Watson (2014: 58) argues that universities foster a cultural or 'soft citizenship'. This is selfawareness and awareness of others which can contribute to the sense of personal 
responsibility and a capacity for 'public reasoning' (Watson, 2014: 59). However, empirical studies of how students at universities in the U.K. learned citizenship found that social interactions outside class are key as ideas from courses 'entered into peer discussion and contributed both to the widening of their political horizons and also to a greater selfconfidence in their capacity to reflect about broadly political issues in more informed ways' (Ahier, et al., 2003: 126). Social learning theory can help here to explain learning by observations and interactions by which individuals interpret, practice and internalise attitudes and behaviour seen around them (Beaumont 2011, citing Bandura 1979; see also Flanagan and Sherrod, 1998).

There are few qualitative studies such as by Ahier et al. (2003) that bring out the constructions of meaning of citizenship from experience at university. They are important because the social experience or the 'hidden curriculum', such as involvement in mixed classes, cooperation on projects and exposure to diverse cultures, can be equally as important as the curriculum (Gutmann, 1987). For example, encountering diverse persons can cause a re-examination of values and assumptions (Finlay, et al., 2010; Gutmann, 1987). A longitudinal survey of students in the United States from first to fourth year found that those exposed to knowledge about racial/ethnic groups in a multicultural education programme were more likely to evidence civic views such as acknowledging similarities among diverse others, appreciating differences in groups and taking the perspective of others (Gurin, et al., 2004). As that study recognises, the emergence of civic views depends on the nature of the experience, which is easier to control in a formal programme whereas we know little of the effect of encountering diverse others informally. This is highly significant: ethnographic research with students points out that the majority of students' time at university is often spent with other students (Nathan, 2005). We know little of how the quality of students' experience affects their constructions of citizenship, especially given the changing landscape of higher education.

The changes in that landscape mentioned above leads to tension between what Gutmann (1987) calls 'a community of learning' and 'a service station for society'. This is the tension between the interests of an autonomous democratic institution pursuing knowledge for its own sake and the pressures of society to provide knowledge that is socially useful. The emphasis in U.K. policy is on the latter namely the economic returns from higher education both to improve skills of the work force and social mobility by producing employable graduates (Department for Business, Innovation and Skills, 2015). Some argue that universities generally - and law schools in particular (Thornton, 2009) - have ceded ground to economic imperatives driven by neoliberal market ideologies (Colby, et al., 2003; Giroux, 2002). This is particularly pertinent in the U.K. where the ranking of universities in league tables, using measures of student satisfaction among other variables, reflects a mainly privatised industry of institutions competing for student attention. Marginson (2018) argues that this cultivates the idea of students as consumers and prevents an agentic construction of identity or 'self-formation'. Studies in Australia found students' conceptions of citizenship to be more personal and intimate because the public space of the university has 
become 'a space of business transaction and portfolio building' that crowds out more civicminded values (Ryan, 2011: 1028; see also in the US Colby, et al., 2003). This does not justify automatically classing the student as 'consumer/customer' as this is under-researched in the U.K. with other influences in their immediate and broader contexts as explained above (Budd, 2017). Indeed, many British universities now explicitly espouse civic aims such as greater engagement in their communities (Goddard, 2010) and the acquisition of attributes of democratic or global citizenship. This is a mixed and contradictory environment of conflicting influences and pressures. How students' experiences in this new environment in the U.K. affect their constructions of civic identity is unknown.

\section{Methodology and research design}

This study was conducted at a law school at a research-intensive elite university with a large, well-resourced legal advice and extracurricular programme. At the time, the university's education strategy sought to cultivate 'responsible and ethical citizenship' as a graduate attribute of its students. The 15 participants were final year law students; ten were female. All were aged between 20 and 24 years and were of nine different ethnicities. Ten of whom had a professional, technical, or managerial breadwinner parent at home. These volunteers, whom I had taught, self-selected for this research. Of those that took part in the interviews and focus groups, half (four) were involved in either political parties, the legal clinic or some form of protest or campaign, whilst the other four were not.

The research design was phenomenological and, to a limited extent, participatory. A phenomenological approach lends access to the meanings given by participants in a social and educational setting (Scott, 1996; following Giddens, 1984). It gives priority to actors' account of social reality (Schutz cited in Cohen et al., 2011), 'voice' to young people (France, 2004) and an understanding of their lived experience (Henderson, et al., 2007). It assumes that people interpret events, circumstances and contexts and act according to those understandings. The intention was to uncover the students' experience and reflections on citizenship and to understand them as 'an individual-in-context' (Mann, 2008: 9). This follows from my ontology above that citizenship can be understood as a lived experience and practice, infused with meaning that is linked to a set of values and beliefs that inform action (civic identity). It is a phenomenon that a young person is consciously aware of and/or can give an account of, if asked.

I recognise there can be 'unacknowledged conditions, unintended consequences, the exercise of tacit skills, and unconscious motivation' (Scott, 1996: 67). This requires a reflexive approach which means 'the way in which all accounts of social settings descriptions, analyses, criticisms, etc. - and the social settings occasioning them are mutually interdependent' (Cohen, et al, 2011: 19). This can be a problem with young participants (France, 2004) whose ability or lack of ability to be reflexive may not be immediately apparent (and could be said to be representative of their experience of citizenship). Another challenge with young people is that of unequal power relationships between researcher and researched (Bennett, et al., 2003). As a lecturer of the participants, 
I was both an insider and an outsider. I was in a position of trust with some experience of the students' study environment that could lend intuitive sense and empathy (Mercer, 2006), whilst I had some control of social relationships with the students in a privileged position as teacher (Kim, 2012). I also accept that there is an '[i]mportant relationship between citizenship education, research processes and worldview that considers young people as citizens with rights to participate and be consulted on matters that concern them' (Starkey, et al., 2014: 427). If we are curious about students' experience as citizens, an investigation should treat them as citizens.

Accordingly, I used a three-stage process of i) an interactive workshop, ii) semistructured interviews, and iii) two small focus groups. I used interactive games drawn from theatre (Boal 2002) to build rapport and trust between participants and with myself. This helped transform the space into one that was more open and collaborative rather than the lecture and tutorial space they were used to. I was clear about my aims that this was not an assessment with right or wrong answers and students were free to disagree with me. In the first workshop, I invited students to define the terms of the study, for example by asking them how they defined and experienced citizenship, and to suggest themes we could later explore in the interviews. In the interviews, I asked students about their personal and educational background before asking them a series of questions of how, when, where, and with whom they had significant experiences of what they understood to be citizenship. In the focus group, I asked students to comment on the themes I had identified from the interviews, and to think of what, if any, citizenship education they would have liked to have had if they started university again. The interviews and the final focus groups were recorded and transcribed. This generated the data below, which I argue is authentic and credible representations of how a diverse group of quite active and confident final year law students, with whom I had formed a good working relationship, expressed their experiences and understandings of citizenship.

\section{Data analysis}

In summary, citizenship was an elusive, resonant, and subjective idea as reported by the students. I suggest that it is 'synthetic' meaning that the students understand citizenship mostly by constructing it from their lived experiences. I separate out periods of learning preuniversity and during university. In both periods, there was a notable influence of proximal figures, such as parents (pre-university) and other students and institutional culture (during university) on their construction of their civic identities. I suggest that at university there is a hybrid hidden curriculum where some students revise their norms when interacting with different others but also adopt individualist and instrumental attitudes emanating from the institution.

In analysing the data, I took a nomothetic approach, meaning I looked for 'patterns, themes... trends, commonalities, generalisations, similarities, laws of behaviour' (Cohen, et al., 2011: 542). This was because little is known about how young adults experience and explain citizenship - I wanted to see what emerged. I arranged the data into codes that 
corresponded with the research questions and then amassed this material into a diagram to perceive broader ideas that explained them or linked them together. I tried to minimise fragmentation of the evidence by referring where necessary to the background of the participant or preceding text. I will now present and discuss the key themes that emerged. I reference comments from interviews or focus groups and use pseudonyms chosen by the students.

\section{Citizenship as a constructed idea}

I will first set the stage for how the students understood citizenship and what conceptions they brought with them to university. Citizenship was both an uncertain and yet meaningful idea for the students. When we explored the ideas that the students used to explain citizenship, it appeared that these were constructed by them individually without much outside help:

'No one has told me anything. I feel like all of this has been me and my experiences and like reflecting on my own experiences' (Sara interview).

'Everyone needs to sort of figure out what path they would like to take and kind of act on it' (Anna interview).

This sense of an individual journey of discovery was evident when I suggested an idea of 'citizenships' to Noctis and he replied:

'Oh $100 \%$. I think I did say something like this in the workshop as well. Where everybody has their own trials and tribulations in their own life' (Noctis interview).

Citizenship appeared as an idea that lacked historical resonance or where the students felt they had a ready or clear reference point. It clearly 'resonated with their own attempts to make sense of their position in society' (Lister et al., 2003: 242) and those attempts were framed as an uncertain struggle. What the students may have been talking about here is not 'citizenship' but a form of civic identity - a narrative of how they conceive of themselves as members of a collectivity. The students talk about citizenship in a way that suggests individualisation: young people come to decide who they are and what they care about on an individual basis in a context of uncertainty and risk. Although this is only superficially the case. As we shall see, they made observations and judgments on their life experiences, which are often coloured by proximal influences and social structures.

Prior to university, the influence of their parents and family upbringing predominated. For Anna, who was of Russian heritage, her ideas of citizenship involved patriotism and community. When I asked her to explain why these were so important to her, she described visiting a war memorial in Hungary: 
'It was so emotional. I can't even believe. I was shocked. I knew it would be emotional for like my mum, and for like my brother. My brother was born in Crimea. But when I got there, I felt it on like my heart so much'. (Anna interview).

These conceptualisations of citizenship are drawn or synthesised from the students' lived experience prior to university. This reinforces the value of a sociological understanding of citizenship as a concept infused with feeling (Osler and Starkey, 2005) and meaning by reference to ethnic, cultural, national and gendered contexts (Isin and Wood, 1999). Another example of this point is Noctis, for whom citizenship was the idea of equality, particularly equal treatment of persons of different races or genders. He told a story of being the only Asian passenger at an airport and the only passenger to be searched:

'This goes back to the whole equality thing. Am I still not an equal citizen? Why do I fit a stereotype? ... You can ask why me, why was I targeted. You feel humiliated, you feel embarrassed and that is how I felt when I got swabbed at the airport'. (Noctis interview).

These students are constructing their own notions of citizenship by drawing upon their surroundings and reflections on their own experiences through the lens of social structures. It follows that their understanding of citizenship will change as they enter the context of a university community with greater proximal influences of other students reflecting many differences (and social structures).

\section{Learning citizenship from other students}

At university, the students noticed clashes between the values and norms that they brought with them and the diverse student community in terms of ethnicity, class, sexuality, and strong differences of opinion. This in turn shaped their understanding of citizenship by reinforcing, undermining or amending their conceptions. For example, Zia came from a Muslim and Pakistani background and met Nigerian students with Christian and Muslim parents:

'... because they're [her Nigerian friends] from a whole different culture you learn so much about what is acceptable in their culture and it makes you question what you thought was acceptable'. (Zia interview).

This could make a student more self-aware by encountering differences they would never see at home. Shani lived at home in a Pakistani Muslim community where homosexuality was shunned. In our focus group, when the students described meeting students from different religions, ethnicity, and classes, it led Shani to mention that he had met gay students. 
'... once I came to university, I was, in a way, kind of forced to speak with these people, and initially I hesitated, but then once I got to see that they had many similar interests to me and their views were very similar to me on a lot of other things, and once I saw them as a minority and also often treated quite negatively, and I related that to my personal experience of being treated differently because of my race or because of my religion'. (Shani Focus group 2).

These are strong examples of empathy across a range of differences - sexuality, religion, and race. The encountering of differences leads to a re-examination of one's own values and assumptions in the hidden curriculum or social experience of university (Ahier, et al., 2003; Finlay, et al., 2010; Gurin, et al., 2004). This is not to say this is always a positive experience. Kira, a black student from a working-class area, conceived of citizenship as inclusion, exclusion, and recognition. He saw this in discriminatory attitudes of other students:

'... a certain tag towards different skin colours l'd say that puts them into a certain category and they are either recognised or they are not'. (Kira interview).

This data brings into sharper relief the question of what kind of experience or quality of experience nurtures democratic civic norms. Shani, who is also from a working-class background, pointed out that university was a unique and illusory bubble different to the outside world because of the high proportion of middle-class students and high diversity, in his opinion. This did not detract from its marked influence even for students like Shani who lived at home. Ginger and Sara said in the focus group that they felt more open to talking to anyone at university, to which Shani replied:

'... you're so used to having your friends and family around you prior to university as people who you'd trust in, but the moment that that's kind of taken away from you, there's this vacuum which you immediately fill up with those who are on your course, in your seminar groups...' (Shani Focus group 2).

The role of friends was stressed by Ginger when they described learning about citizenship in the student community in dialogue and conversation:

'I would say if I was going to rank them [sources of civic learning], it would be my friends and associates and the people. And then it would be student life in general. And then it would be my studies'. (Ginger interview)

Ginger emphasised the importance of close friendships as a relationship built over time that facilitates intimate and trustworthy exchanges across cultural differences. She described learning about arranged marriages, a practice completely alien to her. I asked her 
in the focus group that supposedly there were always lots of opportunities at university to talk with friends and she corrected me:

'Yeah, but only if you ask the question... so yeah, if I hadn't've finally been able to broach the subject [of arranged marriages] with her [a friend], and it's only after probably about a year of knowing her and being like best best friends'. (Ginger Focus group 2).

This theme of friendship as a conduit for exchanging ideas was also mentioned by Shani when he met and became friends with gay students. What these students are suggesting is that their experience of citizenship was most powerfully felt through friendships which can be built across structural divides. What is significant about this data is that it emerged when I asked students for examples and explanations of how they had formed the beliefs, norms and practices that comprised their notion of citizenship. What is surprising is that those with a high political or community involvement (Shani and Zia) described similar experiences to those with less (Abby, Kira). The experiences that appeared to resonate most strongly were not from studies or organised extracurricular activities. This is significant because much of the literature on civic learning in these contexts focuses on the norms and practices generated from scholarly study (Watson, 2014), the involvement in voluntary associations (McFarland and Thomas, 2006), service learning or organised programmes (Gurin, et al., 2004). Instead, it appears that powerful messages occur in student life. This corroborates other studies of mutual social learning (Ahier, et al., 2003; Nathan, 2005).

This provides support for the argument from developmental psychology that we need to go beyond the old political socialisation paradigm and think of young people as 'active agents in their own socialisation' (Amnå, 2012: 623; see also Achen, 2002 and Amnå, et al., 2009 cited there). It builds on what other qualitative researchers at U.K. universities understood as citizenship as a lived experience that is shaped by individuals and shapes them (Ahier, et al., 2003). As a process, I term it 'synthetic': synthetic citizenship describes data where students point to life experiences and/or reflections based upon them to explain citizenship. As I will show next, there are greater and lesser degrees of critical reflection in this process.

\section{A bifurcated hidden curriculum}

What is noticeable are the differences between what the students learn from each other above and their perception of the culture emanating from the institution. They criticised the institution's influence and how it clashed with their aspirations and values. Some suggested that studies and extracurricular activities closed students' minds to broader selfdevelopment, which one associated with citizenship. This arose when we talked about having citizenship education at university. I suggested in the focus group that maybe it was sufficient that they were getting an education and degree which would help them find a job and earn a salary, whilst having lots of extracurricular opportunities. 
Kira: 'I would say no because you're like all right, if you get to this very end point, let's say you're getting a job and now you're like all right, branch out, do all this citizenship stuff, what if you get to a point where you realise that you've been going down a completely wrong path this whole time, like you want to get deeper into citizenship? ...

Zia: 'Because I feel like they're tailor making you to just fit that commercial, like just go into a law job, that's it. What if you do want to work in NGOs and you want to make a difference? What if you want to do that kind of stuff and work for a think tank?' (Kira and Zia Focus group 1).

There were exceptions to this but across the group there was a strong sense that the values, attitudes and culture fostered by the institution were channeling them in certain directions without them having an opportunity to cultivate their own sense of citizenship - a concept which appears entwined with the student's own desire for self-development. For example, slightly later in the same group Kira said this:

'It's more, all right, you know what type of group you're in now, all right if you want to be more part of that group or join a society, or focus on your degree, it's not really more like broaden your thinking or understanding for anything. Citizenship is trying to develop yourself as well. I think it [university life] completely side-lines that'. (Kira Focus group 1).

This is a powerful statement, given the many opportunities at this large, well resourced, Russell Group university, that this particular student sees his own personal and civic development 'side-lined'. Others have observed that law students have 'identified a failure by their legal education to encourage subjective and humanistic concerns as affecting the quality of their education and their ability to develop professionally, personally and morally' (Townsley, 2014: 71; see also Maharg, 2007). This study places such concerns on a civic plane and distinguishes it from similar studies in other disciplines in the U.K. (e.g. McClean, et al., 2017). In the above data students appear reluctantly constrained in their possibilities for self-development. Zia emphasised that this was due to the structure of the law degree, and other students reminded me in interview of the pressure to achieve certain grades to gain employment afterwards.

'You have so many gaps, the way the core modules are designed and the way the law LLB is designed, there are so many gaps in your knowledge... It doesn't give you that because they're too busy teaching you how to solve problem pressures on equity, which is amazing.' (Zia Focus group 1).

'I was told before I came to uni if you get a 2:2 in law your CV will just go into the bin pile generally, and I was like, 'Oh no'.' (Abby interview). 
One must distinguish the positive albeit pressured attitudes, these students tended to demonstrate to their studies and lecturers. For example, Zia's use of the word 'amazing' she professed her enjoyment of her studies and good relationships with lecturers. This is separate to their cynical attitude toward the institution as a whole (as distinct from the law school). They felt that it prioritised image and public relations, especially for commercial gain. In the same group as Kira and Zia, Sara said:

'And it all just felt really like commercial and like they [the university] didn't care about my actual experience [on a human rights internship], they just wanted it to look good on paper'. (Sara Focus group 1).

When I asked whether the surveys used by the university, such as the National Student Survey (NSS), gave them a voice, the attitude was one of scepticism and distrust:

'No, I feel like that's like a front, like they just... I felt like they'd ignored the negatives and oh, this is the positive stuff that we can do'. (Abby Focus group 1).

Notably, when I asked about the university's graduate attributes in the workshop, it was met by incredulity, confusion, and even hostility. This is not to say these students were not interested in their studies and extracurricular pursuits but the priorities of grades and cvbuilding conflict with their civic concerns (see Ryan, 2011). For example, when I asked the students in the same focus group as above if they got involved in concerns in the student community, I was interrupted by this interesting exchange:

Zia: 'How though, Piers? How does a normal student who's trying to get a degree and trying to get like a 2:1 or a first or whatever get involved? And [if one] is doing extracurricular and sports is going to care about like, oh, a consent campaign?'

Kira: 'That is another thing, there's just not enough time is there? Like it's only a handful of your student guild people are like full time...' (Kira and Zia Focus group 1).

What is most noticeable here is that the messages coming from the university are ones that the students feel they have to adapt to. They do not deny that they are keen to secure well paid jobs after university and will utilise whatever is put on offer by the university to do so. The needs of studying and credentialism can constrict horizons for civic learning among these law students (Ryan, 2011), and one student, Anna, suggested that it had gone much further: the possibilities for learning citizenship were non-existent. When I asked her if she learned about citizenship at university, she said:

'No, not at all. Like for me, it is literally like, I come here, I pay my fees, I get what I am given, I sit my exams and I leave with a piece of paper.' (Anna interview). 
When at the end of our interview I asked for feedback, she asked me whether I was shocked by her answers. I replied that I was interested in some of the changes in higher education around pressures of time, increased student numbers, and marketisation. She replied that:

Anna: 'I just wish they didn't hide it so much.

Interviewer: 'Really? What do you mean by that?

Anna: 'Like just be black and white with us. Just tell us sort of like... I'd rather on my first day they'd get up and say you are here to get the degree, just do it like and get out.

Interviewer: 'Really? That's what you feel it is all about.

Anna: 'Probably, I feel and appreciate honesty.' (Anna interview).

One can see here that the tension between the university as 'service station' and a 'community of learning' (Gutmann, 1987) has won out in favour of the former. For Anna, the idea that the university cultivates citizenship is an illusion, almost a deception. Whilst Anna's attitudes were at one end of the spectrum in this group, many spoke of a disconnect between the university's advocacy of graduate attributes like citizenship and the lack of time and incentive to explore what they saw as they own personal civic interests due the importance of obtaining valued credentials (see Kira and Zia above). It lends support to those who argue that there is a losing battle in law faculties, and universities more broadly, to economic imperatives (Giroux, 2002; Thornton, 2009). This goes to wider concerns of instrumentalism found in less discipline specific studies in the U.K. (Jones et al., 2004). However, as we next see the students were less critically aware of how the institution's culture affected their attitudes to learning.

\section{Citizenship as a valued qualification}

The students appeared to believe that learning about citizenship would be desirable, if it would increase their value in the marketplace and of their investment. I suggest this is the influence of a culture of performativity among students (Ball, 2008; Macfarlane, 2015). For example, these views were expressed in one of the focus groups:

'Maybe like a little separate extra qualification thing [citizenship], just to put on your $\mathrm{CV}$, rather than it [citizenship education] be part of your degree, you could say like I went to these focus groups about citizenship because I think it's really important and stuff and that would show you it's like a good person to employ'. (Sara Focus group 1).

'I think it [citizenship education] would add to the feeling of that $£ 9,000$ would feel like it's worth it a bit more if we're having this'. (Zia Focus group 1). 
Notably these views clashed with some of the ideas expressed in the preceding section in the same focus group and yet none commented on the disparity. This is some of the best evidence of how the culture of the institution and a change in national policy has affected the students' concept of citizenship. Because it is synthetic, it draws on the students' experiences of the culture at university: learning about citizenship will be relevant if it is valued by the market. Students are constructing civic identities synthetically under the influence of the prevailing values and structures because citizenship is a social construct affected by context (Turner, 1993).

These comments above came without comment or subsequent observation. It appeared that the students were not critically reflective of how these experiences affected their citizenship or, if they were, that they had much choice. Therefore, the construction of their civic identity, is synthetic but not fully agentic and so takes a hybrid form between what the individual is consciously choosing and what is unconsciously shaped by their environment. There is debate over whether young people are rational and autonomous decision makers or are molded and shaped by their circumstances (Furlong and Cartmel, 2007; Jones, 2009). I suggest that these are synthetic civic identities shaped individually and by social structure with a hitherto unappreciated role of the student community or hidden curriculum of student life, and, of the institution's own hidden curriculum of performativity. Citizenship appears to be synthesised most in the private world of the student community perhaps because the university's domain of study and careers is so driven by the demands of obtaining valued credentials. Whilst similar dynamics have been observed in other countries (Ryan, 2011), what is new here is the varying degrees of critical awareness of the influence of the institution. There is greater critical awareness of the influence of peers and friends and less awareness of the institution's influence, especially where it relates to learning. Therefore, the students' experience of citizenship, whilst shaped prior to university, is pulled in different directions at university, suggesting an uncertain and tense environment in which to cultivate citizenship.

\section{Conclusions}

Citizenship meant very different things to these students. The common thread was that they drew mainly on their experience in order to conceptualise it. They appeared to be active agents in their own socialisation, synthesising their own civic identities. The strongest experiences appeared to be ones with emotional content. We can see here how citizenship was given meaning by reference to various contexts, in particular, ethnicity, class, and gender. The meaning of citizenship for these students was the nature of their membership of a collectivity. This could be seen in Anna's patriotism or Kira's sense of exclusion.

These students conceptualise citizenship in an individualised way by making observations and judgments on their life experiences without any reference points for citizenship. There is a sense that they have to figure it on their own. I agree with youth sociologists (Furlong and Cartmel, 2007; Jones, 2009) that these young people's civic identities are still shaped by proximal influences and social structures. At university, the 
proximal influence of parents and local community was replaced or had to compete with that of peers in the student community (it became a powerful new source of ideas even for those who lived at home like Shani). Accordingly, the norms and values of pre-university life can be amended and softened by interaction with peers, especially those of differing backgrounds. The learning experience is enhanced by feelings of confidence and friendship but should not be idealised. The student community contains prejudices and misconceptions - Kira, for instance, found tacit racial discrimination. It is significant that there were no notable differences in how students talked about the influence of the student community between those who were politically active and those who were not. An area of future research would be to compare and contrast different student communities.

The students understood that they were learning about citizenship from this environment of student life. This is an important social experience or hidden curriculum at university, largely underappreciated by the literature on civic learning in higher education. This hidden curriculum was bifurcated: whilst students are learning from differences and building confidence in conversation with their peers, they are also seeking opportunities to obtain value for their investment as encouraged by the institution's messages and higher education policy. Therefore, learning about citizenship is understood as something that could give them value for money and enhance their credentials for employment. I found less awareness here of how attitudes were affected by the institution and policy; instead I found a certain cynicism and reluctant adaptation to the needs of their studies. It would be interesting to conduct a study to compare disciplines with differing emphases on vocational orientation.

The meaning that citizenship has for these students is accepting of differences but also at times discriminatory, discursive and dialogic while individualist, instrumentalist and wary of performance. Because it is synthetic, it is multifaceted and hybrid: reflective of the diverse backgrounds, which generated empathy or stereotyping, and absorbing the transactional and instrumental attitudes fostered towards degree results and cv building.

This is a small sample from a particular year group in a specific discipline. However, these findings are noteworthy because they are based on a qualitative and partly participatory methodology on an issue rarely investigated. As such it contributes to current narratives over whether the aims of higher education are being subsumed to economic ends (Marginson, 2018; Heilbronn, et al., 2018) or if a social justice agenda can co-exist with commercial imperatives, albeit in tension (Mann, 2008; Ryan, 2011).

Overall, there is an issue of credibility for universities: by promoting citizenship, whilst nurturing ideas and attitudes that dilute or undermine it, universities may well be engendering cynicism and scepticism among students about an old and valuable idea - that higher education can cultivate citizens not just employable individuals. This raises difficult questions for legal education in particular, if it aspires to nurture citizens with responsibilities for justice. 


\section{Acknowledgements}

I am grateful to Tristan McCowan, participants at the Higher Education Close Up conference in Cape Town, South Africa, in November 2018, and to anonymous reviewers for their helpful and constructive comments on an earlier draft of this article. I also appreciate the support given by the Centre for Professional Legal Education and Research at the University of Birmingham for this research.

\section{Author Biography}

Piers von Berg worked on international development programmes in the former Soviet Union in the fields of citizenship education, elections and local government from 2000-2006. He returned to the U.K. to practice as a barrister from 2010-2017, specialising in the law affecting children and young people. He started teaching law full time from 2015. His research focuses on youth justice, citizenship and citizenship education. He is currently completing a Doctorate in Education at the Institute of Education, University College London, on undergraduates' conceptualisations of citizenship and the effects of an intervention to cultivate undergraduates' civic identities.

\section{References}

Ahier, J., Beck, J. \& Moore, R. 2003. Graduate Citizens? Issues of Citizenship and Higher Education. London: RoutledgeFalmer.

Amnå, E. 2012. How is civic engagement developed over time? Emerging answers from a multidisciplinary field. Journal of Adolescence 35, 611-627.

Annette, J. 2010. The challenge of developing civic engagement in higher education in England. British Journal of Educational Studies, 58(4): 451-463.

Archer, M. 2000. Being human: The problem of agency. Cambridge: Cambridge University Press.

Ashwin, P. \& McVitty, D. 2015. The meanings of student engagement: Implications for policies and practices. In Curaj A., Matei L., Pricopie R., Salmi J. \& Scott P. (eds.) The European Higher Education Area. Cham: Springer, 343-359.

Ball, S. 2008. Performativity, privatization, professionals and the state. In Cunningham, B. (ed) Exploring Professionalism. Institute of Education, University of London, 50-72.

Bandura, A. 2001. Social Cognitive Theory: An Agentic Perspective. Annual Review of Psychology, 52: 1-26.

Barber, M., Donnelly, K. \& Rizvi, S. 2013. An Avalanche is Coming: Higher Education and the Revolution Ahead. London: Institute for Public Policy Research.

Barrie, S. \& Prosser, M. 2004. Generic graduate attributes: citizens for an uncertain future. Higher Education Research and Development, 23(3): 243-246.

Bennett, A., Cieslik, M. \& Miles, S. (eds). 2003. Researching Youth. Basingstoke: Palgrave MacMillan. 
Benson, L, Harkavy, I. \& Puckett, J. 2007. Dewey's Dream: Universities and Democracies in an Age of Education Reform: Civic Society, Public Schools, and Democratic Citizenship. Boston: University of Massachusetts.

Boal, A. 2002. Games for Actors and Non-Actors. 2nd Edition, trans. A Jackson. Abingdon: Routledge.

Budd, R. 2017. Undergraduate orientations towards higher education in Germany and England: Problematizing the notion of 'student as customer'. Higher Education: The International Journal of Higher Education Research, 73(1): 23-37.

Bynner, J., Dolton, P., Feinstein, L., Makepiece, G., Malmberg, L. \& Woods, L. 2003. Revisiting the Benefits of Higher Education: A Report by the Bedford Group for Lifecourse and Statistical Studies. Institute of Education. Bristol: Higher Education Funding Council for England.

Clarke, J., Coll, K., Dagnino, E. \& Neveu, C. 2014. Disputing Citizenship. Bristol: Policy Press.

Colby, A., Ehrlich, T., Beaumont, E. \& Stephens, J. 2003. Educating Citizens Preparing America's Undergraduates for Lives of Moral and Civic Responsibility. San Francisco: Jossey-Bass.

Cohen, L., Mannion, L. \& Morrison, K. 2011. Research Methods in Education. 7th Edition. Abingdon: Routledge.

Côté, J. \& Schwartz, S. 2002. Comparing psychological and sociological approaches to identity: identity status, identity capital, and the individualization process. Journal of Adolescence, 25: 571-586.

Davies, I., Fülōp, M., Bauer, T., Krull, E., Raubik, R. \& Roland-Lévy, C. 2002. Implementing citizenship education: Issues from Higher education in Europe. Citizenship, Social and Economics Education, 5(1): 53-61.

Department for Business, Innovation and Skills. 2015. Fulfilling Our Potential, Teaching Excellence, Social Mobility and Student Choice. Cm 9141 [Green Paper]. HMSO.

Erikson, E. 1968. Youth, Identity and Crisis. New York: WW Norton Company.

Finlay, A., Wray-Lake, L. \& Flanagan, C. 2010. Civic Engagement during the transition to adulthood: Developmental opportunities and social policies at a critical juncture. In Sherrod, L., Torney-Purta, J. \& Flanagan, C. (eds.) Handbook of Research on Civic Engagement in Youth. Hoboken, New Jersey: John Wiley and Sons Inc.

Flanagan, C. \& Sherrod. 1998. Youth political development: An introduction. Journal of Social Issues, 54(3): 447-456.

Flanagan, C. \& Levine, P. 2010. Civic engagement and the transition to adulthood. The Future of Children, 20(1): 159-179.

France, A. 2004. Young people. In Fraser, S., Lewis, V., Ding, S., Kellett, M. \& Robinson, C. (eds.) Doing Research with Children and Young People. London: Sage Publications.

Furlong, A. \& Cartmel, F. 2007. Young People and Social Change. 2nd Edition Maidenhead: Open University Press. 
Furlong, A. \& Cartmel, F. 2009. Higher Education and Social Justice. Maidenhead: Open University Press.

Giddens, A. 1991. Modernity and Self Identity: Self and Society in the Late Modern Age. Oxford: Polity.

Giroux, H. 2002. Neoliberalism, corporate culture, and the promise of higher education: The university as a democratic public sphere. Harvard Educational Review, 72(4): 425-463.

Goddard, J. 2010. Reinventing the Civic University. Provocation 12, September 2009. Available at:

https://www.nesta.org.uk/sites/default/files/reinventing_the_civic_university.pdf. (accessed 1 December 2016).

Gurin, P., Nagda, B. \& Lopez, G. 2004. The benefits of diversity in education. Journal of Social Issues, 60(1): 17-34.

Gutmann, A. 1987. Democratic Education. Princeton, New Jersey: Princeton University Press.

Hart, S. 2009. The 'problem' with youth: Young people, citizenship and the community. Citizenship Studies, 13(6): 641-657.

Haste, H. 2010. Citizenship education: A critical look at a contested field. In Sherrod, L., Torney-Purta, J. \& Flanagan, C. (eds.) Handbook of Research on Civic Engagement in Youth. Hoboken: John Wiley and Sons Inc.

Heilbronn, R., Doddington, C. \& Higham, R. 2018. Dewey and Education in the 21st Century: Fighting Back. Bingley, U.K.: Emerald Publishing.

Henderson, S., Holland, J., McGrellis, S., Sharpe, S. \& Thomson, R. 2007. Inventing Adulthoods: A Biographical Approach to Youth Transition. London: SAGE Publications.

Isin, E. 2017. Performative citizenship. In Shachar, A., Bauböch, R., Bloemraad, I. \& Vink, M. (eds.) The Oxford Handbook of Citizenship. Oxford: Oxford University Press.

Isin, E. \& Turner, B. 2002. Citizenship studies: An introduction. In Isin, E. \& Turner, B. (eds.) Handbook of Citizenship Studies. London: Sage.

Isin, E. \& Wood, P. 1999. Citizenship and Identity. London: SAGE Publications.

Jeffs, T. 2005. Citizenship, youth work and democratic renewal. Available at: http://infed.org/mobi/citizenship-youth-work-and-democratic-renewal/. (accessed 1 December 2016).

Jones, G. 2009. Youth. Polity Press: Cambridge.

Jones, G., O'Sullivan, A. \& Rouse, J. 2004. 'Because it's worth it'? Education beliefs among young people and their parents in the U.K. Youth and Society, 36(2): 203-26.

Joppke, C. 2007. Transformation of citizenship: Status, rights, identity. Citizenship Studies, 11(1): 37-48.

Kim, H. 2012. Research with children: challenges and dilemmas as an insider researcher. Early Child Development and Care, 182(2): 263-276.

Kymlicka, W. 2002. Contemporary Political Philosophy: An Introduction. 2nd Edition. Oxford: Oxford University Press. 
Lister, R., Smith, N., Middleton, S. \& Cox, L. 2003. Young people talk about citizenship: Empirical perspectives on theoretical and political debates. Citizenship Studies, 7(2): 235-253.

Macfarlane, B. 2015. Student performativity in higher education: Converting learning as a private space into a public performance. Higher Education Research \& Development, 34(2): 338-350.

Maharg, P. 2007. Transforming Legal Education: Learning and Teaching the Law in the Early Twenty First Century. Aldershot: Ashgate Publishing Ltd.

Mann, S. 2008. Study, Power and the University. Milton Keynes. Open University Press.

Marginson, S. 2018. Higher Education as Self-Formation: An Inaugural Professorial Lecture. London: UCL IOE Press.

McClean, M., Abbas, A. \& Ashwin, P. 2017. Quality in Undergraduate Education. How Powerful Knowledge Disrupts Inequality. London: Bloomsbury Academic.

McCowan, T. 2009. Rethinking Citizenship Education, A Curriculum for Participatory Democracy. London and New York: Continuum International Publishing Group.

McCowan, T. 2012. Opening spaces for citizenship in higher education: Three initiatives in English universities. Studies in Higher Education, 37(1): 51-67.

McFarland, D. \& Thomas, R. 2006. Bowling young: How youth voluntary associations influence adult political participation. American Sociological Review, 71: 401-25.

Mercer, J. 2006. The challenges of insider research in educational institutions: Wielding a double-edged sword and resolving delicate dilemmas. Oxford Review of Education, 33(1): 1-17.

Mezirow, J. 1990. Fostering Critical Reflection in Adulthood: A Guide to Transformative and Emancipatory Learning. San Francisco: Jossey Bass.

Nagaoka, J., Farrington, C.A., Ehrlich, S.B. \& Heath, R.D. 2015. Foundations for Young Adult Success: A Developmental Framework. Concept paper for research and practice. The University of Chicago Consortium on Chicago School Research. Available at: https://consortium.uchicago.edu/publications/foundations-young-adultsuccess-developmental-framework (accessed 1 June 2017).

Nathan, R. 2005. My Freshman Year: What a Professor Learned by Becoming a Student. New York: Cornell University Press.

Newman, J. 2008. The Idea of a University Defined and Illustrated: In Nine Discourses Delivered to the Catholics of Dublin. Available at: http://www.gutenberg.org/files/24526/24526-pdf.pdf (accessed 28 October 2019).

Nussbaum, M. 2003. Cultivating humanity in legal education. University of Chicago Law Review, 70: 265-279.

Osler, A. \& Starkey, H. 2005. Changing Citizenship. Maidenhead: Open University Press.

Pollard, A. 2003. Learning through life - higher education and the lifecourse of individuals. In Watson, M. \& Slowey, M. (eds.) Higher Education and the Life Course. Maidenhead: SRHE and Open University Press. 
Ryan, M. 2011. Productions of space: civic participation of young people at university. British Educational Research Journal, 37(6): 1015-1031.

Scott, P. 2010. Higher education: An overview. In Peterson, P., Baker, E. \& McGaw, B. (eds.) International Encyclopedia of Education. 3rd Edition. Oxford: Elsevier.

Sennett, R. 2001. Street and office: Two sources of identity. In Hutton, W. \& Giddens, A. (eds.) On the Edge. Living with Global Capitalism. London: Vintage.

Shachar, A., Bauböck, R., Bloemraad, I. \& Vink, M. 2017. Introduction: Citizenship - quo vadis? In Shachar, A., Bauböck, R., Bloemraad, I. \& Vink, M. (eds.) The Oxford Handbook of Citizenship. Oxford: OUP.

Shaw, A., Brady, B., McGrath, B., Brennan, M.A. \& Dolan, P. 2014. Understanding youth civic engagement: debates, discourses, and lessons from practice. Community Development, 45(4): 300-316.

Smith, N., Lister, R., Middleton, S. \& Cox, L. 2005. Young People as real citizens: Towards an inclusionary understanding of citizenship. Journal of Youth Studies, 8(4): 425-443.

Smyth, J. 2016. Series Editor's Preface. In Arvanitakis, J. \& Hornsby, D. (eds.) Universities: The Citizen Scholar and the Future of Higher Education. Basingstoke: Palgrave MacMillan.

Starkey, H., Akar, B., Jerome, L. \& Osler, A. 2014. Power, Pedagogy and Participation: ethics and pragmatics in research with young people. Research in Comparative and International Education, 9(4): 426-440.

Storrie, T. 2004. Citizens or what? In Roche, S., Tucker, S., Tomson, R. \& Flynn, R. (eds.) Youth in Society. London: SAGE Publications.

Sukarieh, M. \& Tannock, S. 2016. On the political economy of youth: A comment. Journal of Youth Studies, 19(9): 1281-1289.

Thornton, M. 2009. The law school, the market and the new knowledge economy. German Law Journal, 10(6): 641-668.

Townsley, L. 2014. Thinking like a lawyer ethically: Narrative intelligence and emotion. Legal Education Review, 24, 69-93.

Turner, B. 1993. Contemporary problems in the theory of citizenship. In Turner, B. (ed.) Citizenship and Social Theory. London: Sage.

Walker, M. \& McClean, M. 2013. Professional Education, Capabilities and the Public Good: The Role of Universities in Promoting Human Development. London: Routledge.

Watson, M. 2014. The Question of Conscience: Higher Education and Personal Responsibility. London: Institute for Education Press.

Wood, B.E. 2014. Researching the everyday: Young people's experiences and expressions of citizenship. International Journal of Qualitative Studies in Education, 27(2): 214-232.

Youniss, J., McLellan, J. \& Yates, M. 1997. What we know about engendering civic identity. The American Behavioural Scientist, 40(5): 620-631.

Youth Citizenship Commission. 2009. Final Report of the Youth Citizenship Commission. Available at: 
https://www.liverpool.ac.uk/media/livacuk/politics/documents/YCC_Final_Report.pdf (accessed 20 December 2016). 